
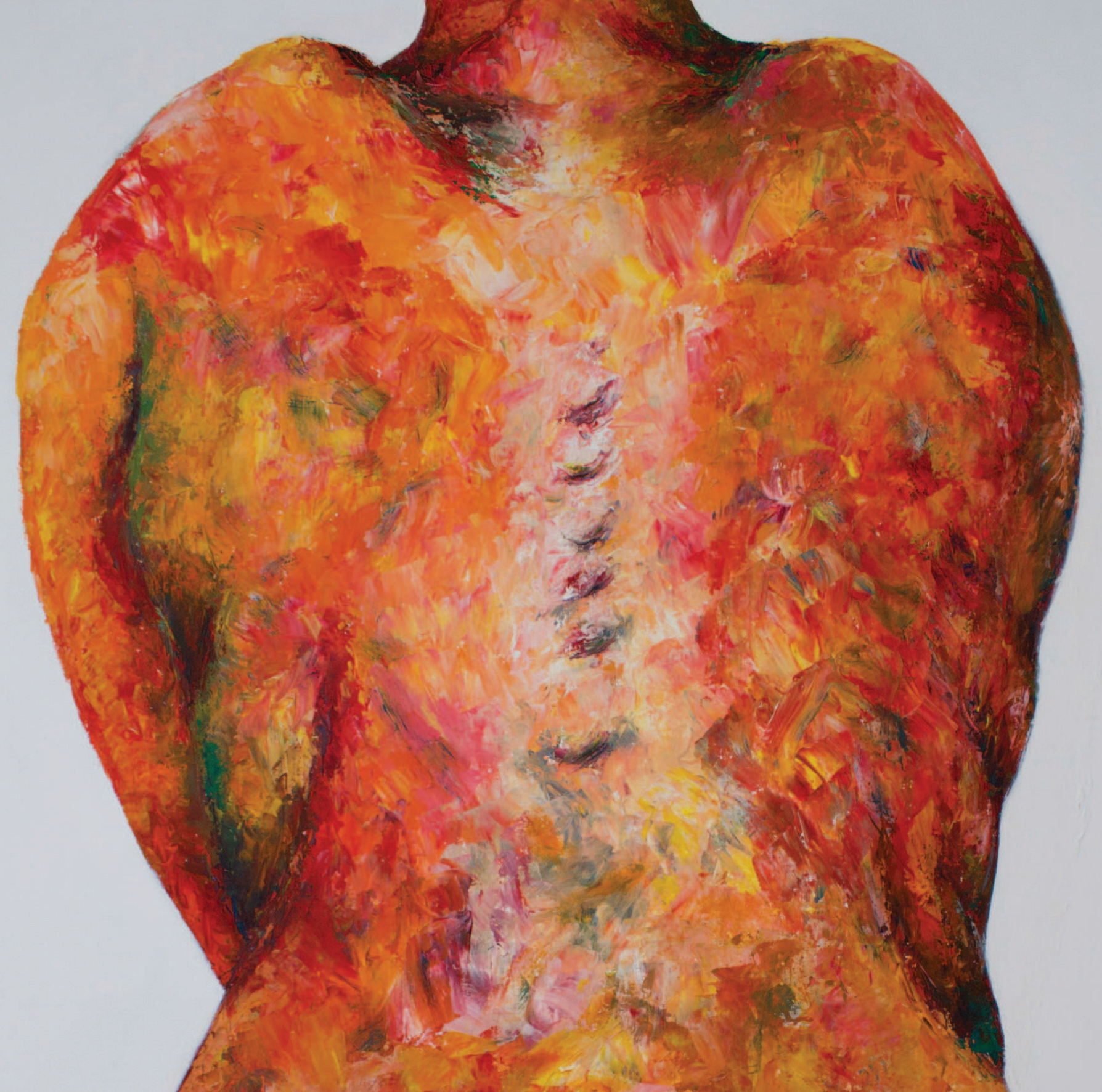

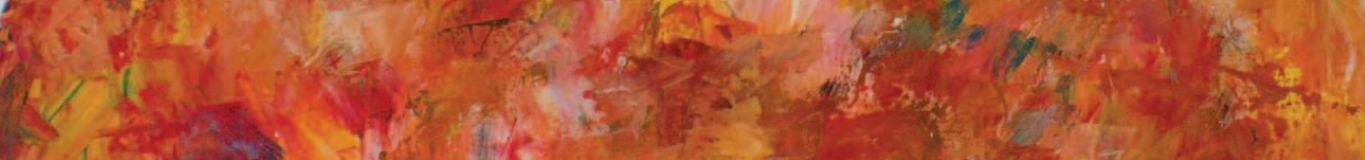

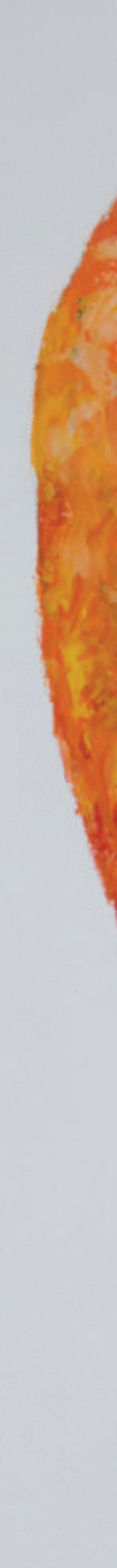

1

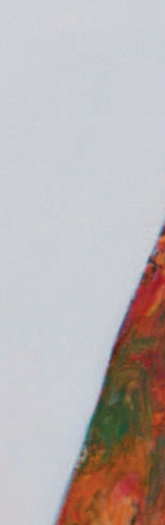

2.

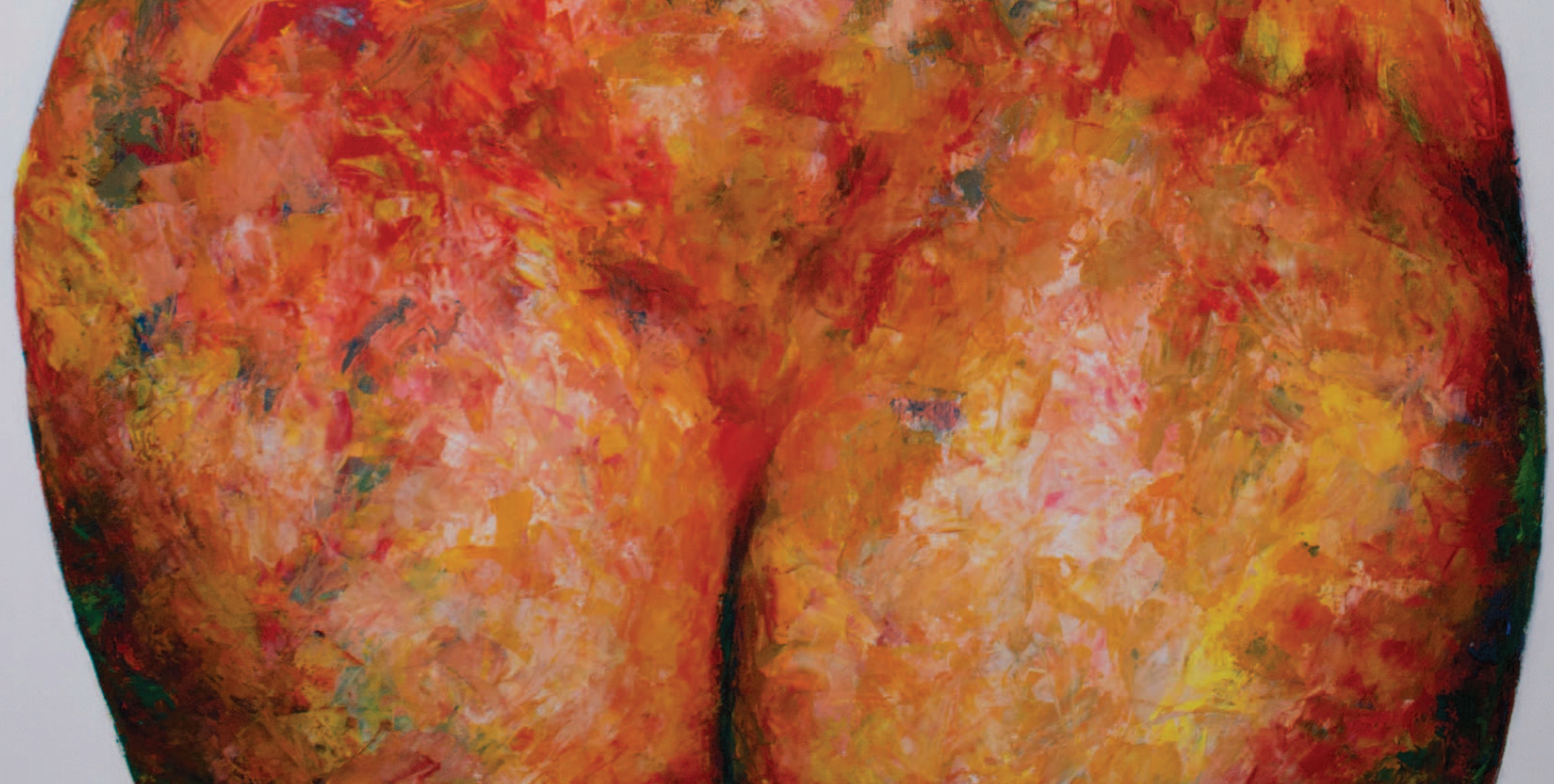




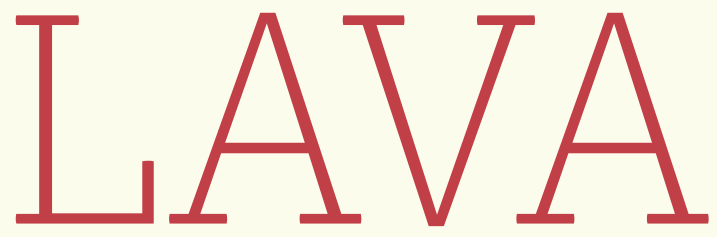

Matéria liquida lançada pelos vulcões.

Torrente, enxurrada, curso. 


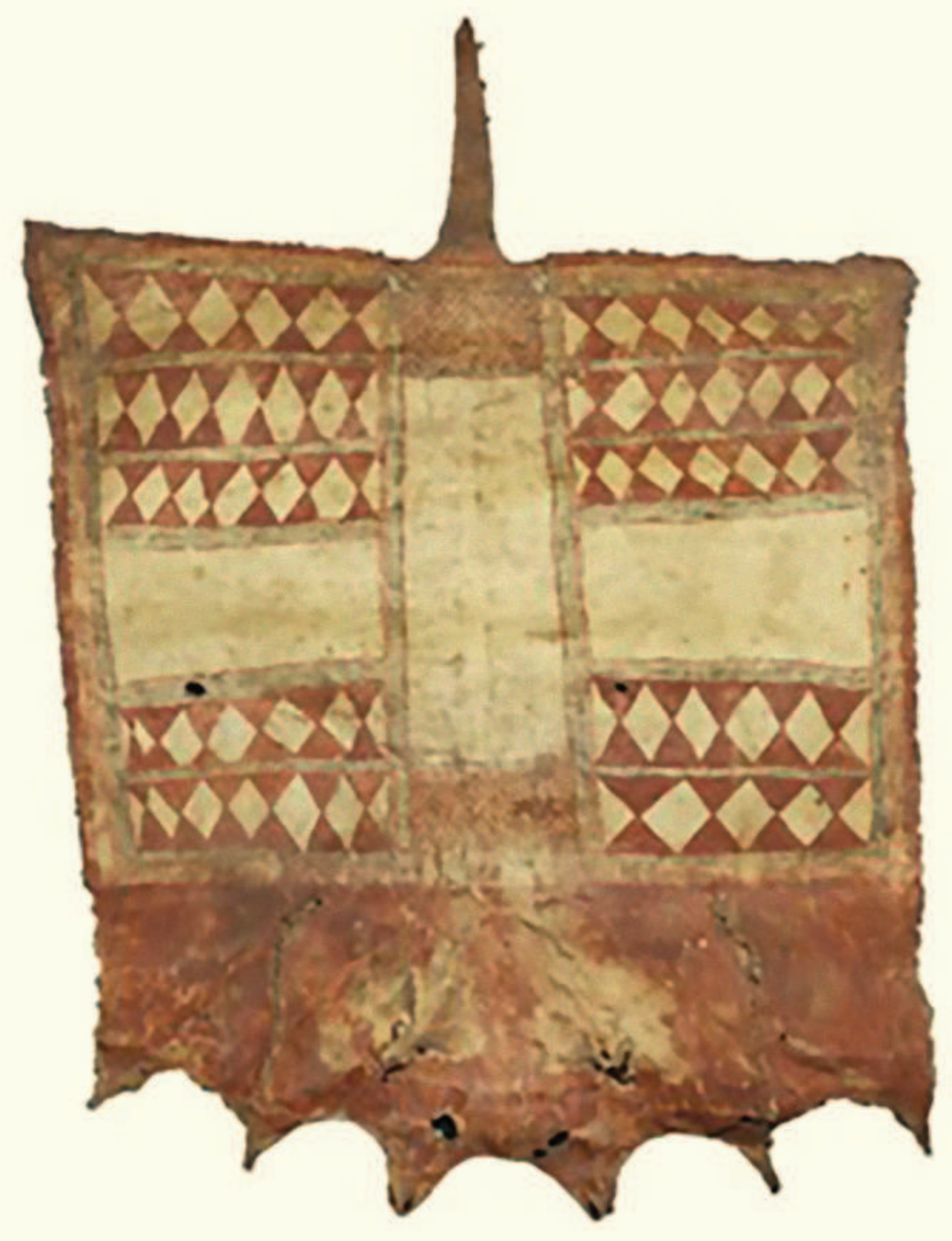

\section{LITERATURAS DA FLORESTA}

Textos de conclusão do curso ministrado no segundo semestre de 2014 e indicados para publicação pela Profa Lúcia Sá. 


\section{O MEMBI \\ E O ALAÚDE - \\ MÁRIO DE ANDRADE LÊ GONÇALVES DIAS}

- MARCELO MARANINCHI

\section{RESUMO}

Romantismo e modernismo encontraram na cultura indígena elementos essenciais para recriar poeticamente 0 Brasil. O artigo apresenta a marginália de Mário de Andrade (1893-1945) na poesia indianista de Gonçalves Dias (1823-1864), analisando as linhas de força do "diálogo" entre o polígrafo modernista e seu predecessor romântico.

Palavras-chave: Mário de Andrade, Gonçalves Dias, Marginália, Indianismo.

\section{ABSTRACT}

Romanticism and modernism found in the amerindian culture essential elements for recreating Brazil in poetry. This study presents Mário de Andrade's (1893-1945) marginalia in Gonçalves Dias' (1823-1864) indianist poems and analyses the major themes in the "dialogue" between the modernist writer and his romantic predecessor.

Keywords: Mário de Andrade, Gonçalves Dias, Marginalia, Indianism.

ntes de diagnosticar como mal-estar de classe a sensação de que
temos no Brasil uma cultura postiça, inautêntica, imitada, Ro-
berto Schwarz (2006) menciona o adensamento da crítica como um dos remédios para o falso problema. Machado de Assis, Mário de Andrade e Antonio Candido são exceções honrosas, confirmam a regra de que, entre nós, pouco se leem as gerações anteriores, o que provoca a permanente tensão de começar tudo do zero.

Mário de Andrade empenhou-se em superar esse mal-estar ou, quem sabe, envenená-lo até o limite da transformação social. Intelectual participante, criador do Departamento de Cultura e produtor de obra malsã, o autor de $O$ Carro da miséria dedicou-se intensamente ao exercício da crítica. Em particular, o interesse dispensado à poesia romântica — como crítico e 
artista - integra o projeto estético-ideológico de criar uma obra brasileira, nutrida por sua pesquisa criativa, musicada pelos ritmos populares e pela fala cotidiana, que não se deveria mais reprimir na criação erudita.

O propósito deste artigo é apresentar a marginália de Mário nos poemas indianistas de Gonçalves Dias, verificando como se relaciona com seu projeto de pensar e produzir cultura brasileira, projeto marcado pela apropriação crítica de matrizes múltiplas, nacionais e estrangeiras.

A biblioteca do autor guarda quatro edições de Gonçalves Dias: os volumes das Obras posthumas (1909) dedicados à poesia, à prosa, ao teatro e à história etnográfica; os dois tomos das Poesias (1919), organizados por Joaquim Norberto de Souza Silva; as Obras poéticas (1944) editadas por Manuel Bandeira, e os fascículos do Dicionário da Lingua Tupy. ${ }^{1}$

Por sua natureza, a marginália encena o processo de interpretação, nem sempre livre de contradições, ganhando corpo no correr do lápis e das páginas. A parcela inscrita nesses volumes situa-se em larga medida no âmbito do livro Lirismo romântico no Brasil, projeto mencionado na correspondência com Manuel Bandeira. Em carta de 1925, o autor de Macunaíma confirma a intenção de preparar um estudo sobre o romantismo brasileiro; em 1931, centenário de Álvares de Azevedo, prevê um ano consagrado aos românticos ${ }^{2}$.

O projeto de livro sobre o Lirismo romântico, de cujo plano não se tem conhecimento exato, ficou latente ao longo dos anos 1920. Restam, como testemunho, as crônicas dedicadas aos românticos no Diário Nacional e os ensaios "Amor e Medo" (1931) e "Castro Alves" (1939), reunidos em Aspectos da literatura brasileira. A data de publicação dos trabalhos, assim como a menção na correspondência e o número dos volumes na Bibliografia para Na pancada do ganzá, sugerem que a parte mais expressiva das notas de margem tenha sido escrita entre o final da década de 1920 e o começo dos anos 1930.

As anotações pontuam o andamento da leitura e registram aspectos de interesse para o leitor, que analisa e se apropria do texto. A relação da marginália com as crônicas e ensaios de Mário confere aos exemplares na biblioteca do escritor a natureza dupla de livro e manuscrito. Da mesma forma que se ligam à obra publicada, os documentos remetem a outras esferas dos arquivos da criação, como a correspondência e o fichário analítico.

As anotações de Mário de Andrade na obra indianista de Gonçalves Dias acham-se no tomo segundo das Poesias, edição de 1919. No volume, constam como poemas americanos "Canção do exílio", "O canto do guerreiro", "O canto do piaga", "O canto do índio", "Caxias", "Deprecação", "Tabira, dedicatória aos pernambucanos”, “Tabira”, "O gigante de pedra”,
[1] Obras posthumas de A. Gonçalves Dias: precedidas de uma notícia da sua vida e obras pelo dr. Antonio Henriques Leal. Rio de Janeiro/Paris: H. Garnier, 1909. 4 v. (2) Poesias de Gonçalves Dias: Nova edição organizada e revista por J. Norberto de Souza Silva. Rio de Janeiro: Garnier, 1919, 2 v. (3) Obras poéticas de A. Gonçalves Dias. Organização, apuração do texto, cronologia e notas por Manuel Bandeira. São Paulo: Companhia Editora Nacional, 1944, 2 v. (4) Diccionario da língua tupy: chamada língua geral dos indígenas do Brasil. s.L.: s.c.p.,19--. Os livros e documentos de Mário de Andrade aqui mencionados integram o patrimônio do Instituto de Estudos Brasileiros da Universidade de São Paulo (IEB/USP).

[2] Em 11 de maio de 1925, MA escreve: "Você me fala dum estudo meu sobre o Romantismo brasileiro. Já pensei nisso muitas e muitas vezes. É possível que o realize um dia. Já tenho até algumas notas sobre isso. Isto é, sobre uma coisa um pouco mais larga e de que desisti: uma História crítica da poesia brasileira até nossos dias". Passados seis anos, a carta de 20 de março de 1931 revela o projeto em latência: "Manu, recebi sua carta faz uns dez minutos e já respondo, foi só o tempo de acabar a leitura de Boabdil de Gonçalves Dias onde estava à procura dos sequestros causados nos românticos pelo tema do 'Amor e medo' que foi por todos glosado à farta [...] creio que dedicarei meu ano aos românticos". (MORAES, 2001, pp. 210 e 490) 
"Leito de folhas verdes", "I-juca-pirama", "Marabá", "Canção do Tamoio", "A mangueira", "A mãe-d'água" e "Os Timbiras".

Em "Tabira" ("Para o vosso terreiro vos chamo"), assim como na "Canção do exílio" ("Não permita Deus que eu morra / Sem que eu volte para lá"), Mário realça o aspecto lexical: sublinha a preposição e acrescenta uma cruzeta à margem. Faz o mesmo em muitos outros versos, sejam eles parte ou não da obra indianista, com o fim de contrastar o para e a forma coloquial, mais corriqueira, pra. Em Gonçalves Dias, a forma culta é contabilizada com maior frequência. Ao examinar a eficácia e os limites da poesia engajada de Castro Alves, Mário atribui ao poeta baiano o papel de primeiro sistematizador do pra. De modo a relacionar a experiência romântica com a própria, modernista, afirma: "sessenta anos mais tarde outros lhe retomariam a lição" (1974, p. 121). A partir de Losango cáqui o pra é adotado regularmente:

Eu sou a Fama de cem bocas

Pra beijar todas as mulheres do mundo!

Em meio à descrição das tabas dos Timbiras, nas estrofes iniciais do Canto II, os versos

Rudas palhoças só! que mais carece

Quem há de ter somente um sol de vida,

Jazendo negro pó antes do ocaso?

suscitam o comentário de que Gonçalves Dias prefere o verbo carecer a precisar. Na segunda estrofe do Canto IV, chegado o mensageiro timbira à taba dos Gamelas para selar o entendimento entre as tribos, a ênfase do pleonasmo é realçada:

Embora; mas porém amigas quedem

Do Timbira e Gamela as grandes tabas;

O aspecto linguístico, marcado sistematicamente por Mário de Andrade, integra esses exemplos e anotações a A gramatiquinha da fala brasileira, dossiê de documentação farta no arquivo do escritor. Junto a considerações sobre morfologia, dicção e psicologia da fala brasileira, o projeto, buscando reunir constâncias da expressão oral, enumera brasileirismos vocabulares e sintáticos, entre os quais se acham mais exemplos de Gonçalves Dias, como o verso de "Tabira": 
Também na obra de Álvares de Azevedo, Casimiro de Abreu e Castro Alves, como a marginália e os manuscritos atestam, Mário encontra material abundante para a coleção de brasileirismos e elogia a poesia romântica pela fidelidade à fala popular. ${ }^{3}$ Gonçalves Dias aparece n'A gramatiquinha como "ligeira exceção" - as muitas c'rôas encontradas em sua obra devem ter contribuído para isso -, mas sua posição moderna sobre a língua brasileira é identificada por Mário com um traço duplo à margem: "cuia virá a ser tão clássico como porcelana, ainda que a não achem tão bonita" (DIAS in REVISTA DA ABL, 1932, p. 111).

Também no âmbito lexical, a impropriedade de termos na caracterização do cenário é realçada. No Canto III de "Os Timbiras", o escritor modernista grifa as donas das tabas de Itajuba. Mesmo assim, considera que nas "Americanas" em geral o poeta maranhense "se esquece com muita arte de Portugal portuguesista".

A voz dos animais é outro elemento destacado. Na sétima estrofe de "O canto do guerreiro", Mário sublinha o carpido triste de uma ave a cantar. À margem, anota "zoof". Em "O canto do Piaga", oitava estrofe, os versos

\section{Não ouviste a coruja, de dia, \\ Sons estrídulos torva soltar?}

recebem a mesma indicação, que se acha também em "Os Timbiras": no Canto I, as aves "docemente atitam"; no Canto II, ouvem-se os "tristonhos pios"que "a acauã desata".

As marcações servem à pesquisa Zoofonia, termo tomado de empréstimo de Hercule Florence para designar o ramo científico dedicado à voz dos animais. Em entrevista, Mário (1983, p. 93) atribui a ideia à leitura de Green Mansions: a romance ofthe tropical forests, de William Henry Hudson. Desenvolvido por anos, o projeto se liga ao Dicionário musical brasileiro - no qual o termo zoofonia figura como entrada - e também a $O$ banquete, trabalho incompleto, cujo capítulo oitavo seria "O passeio dos pássaros".

O manuscrito Zoofonia, no arquivo do escritor, é composto de documentos musicais, recortes de jornal e notas de trabalho extraídas de publicações ou colhidas in loco por Mário e seus colaboradores. A abundância de registros fascina. Psitacídeos tucanos picapaus tapeis tangarás siriemas uritutus sericoias galos andorinhas macacos guaribas saguis capoeiras corós onças grachains raposas jacarés moriches melros corvos cucos pombas pavões rincham orneam esturram ladriscam pipitam grasnam chilream trinam dobram galream sussurejam cucuritam grulham.
[3] "Brasil romântico, prurido de liberdade, primeira liberdade, a política, a mais consciente de todas as liberdades, e por isso mesmo que consciente um pouco forçada. Nesta fase pelo milagre da libertação nós falávamos o brasileiro, e a língua falada pelos nossos poetas, com ligeira exceção de G. Dias (e assim mesmo!) é a língua falada pelo povo. Fase caótica primitiva em que o Brasil é livre, [...] dá as tendências essenciais da futura fala brasileira" Manuscrito digitalizado e transcrito em ALMEIDA, 2013, v. 2, p. 784. 
Os exemplos fazem lembrar os inventários do narrador-rapsodo em $\mathrm{Ma}$ cunaíma, enumerados assim sem vírgulas.

Ainda no capítulo dos inventários, agora no largo terreno do Dicionário musical brasileiro, de publicação póstuma, a marginália contém diversos exemplos encontrados na poesia indianista para servir de abonação aos verbetes. Na sexta estrofe de "O canto do guerreiro", o crítico sublinha o instrumento indígena e anota ao lado "dic":

Se as matas estrujo

Co'os sons do Boré

Na folha de guarda das Poesias, Mário resume as referências obtidas do volume: lista palavras, indica as respectivas páginas e, ao final, depois de as passar a limpo, risca, para sinalizar a tarefa concluída. O mesmo procedimento é adotado nos demais volumes da poesia romântica que integram sua biblioteca, assim como em grande número de obras da Bibliografia para Na pancada do ganzá. Os poemas americanos oferecem ao Dicionário musical idealizado por Mário cascavéis, borés, maracás

Ouve o anúncio do horrendo fantasma,

Ouve os sons do fiel Maracá

nênias

Vivem homens de pel' cor da noite

Neste solo, que a vida embeleza;

Podem, servos, debaixo do açoite,

Nênias tristes da pátria cantar!

membis e clarins

$\mathrm{O}$ atroador membi soprou com força.

O tronco, o arbusto, a moita, a rocha, a pedra,

Convertem-se em guerreiros; mais depressa,

Quando soa o clarim, núncio de guerra,

A este verso do Canto I de "Os Timbiras" Mário acrescenta o comentário:

Me parece que G. Dias se engana. O membi era uma flauta e portanto não atroava. 
Com um fio, liga um búzio ("Aos sons do cavo búzio conhecido") a outro membi na página seguinte ("Os sons guerreiros do membi troante"). O Dicionário musical retraça o percurso de leitura e apropriação e ajuda a esclarecer o sentido das marcações:

MEMBI (s.m.) - Instrumento de sopro; empregado de modo confuso por diversos autores, podendo significar uma trombeta ou buzina cerimonial ou simplesmente qualquer instrumento soprado.

1. Gonçalves Dias nos "Timbiras" (Poesias, v. 2, 1919, p. 161) fala que Itajubá "[...] o atroador membi soprou com força". Noutro passo (III ${ }^{\circ}$ Canto) vem ainda: "Nunca o membi guerreiro [...] troou". Isso indica que o Membi é instrumento guerreiro. Sempre soube que Membi era uma flauta. O qualificativo "atroador" parece estar mal colocado. Montoya um pouco atrapalhadamente diz que "Flauta, bocina, etc." são "mimbí tarará" em guarani. Mas especifica na parte guarani-espanhol do Vocabulário que mimbí é "flauta, chirimia y cosa semejante", ao passo que trombeta, clarim, é "mimbí tarará" ou "mimbítererê". Isso dá um bocado mais de luz e mostra que Gonçalves Dias empregou membi, abreviadamente, por membi-tarará. O que não podia fazer pois membi tem significado próprio. Aliás duas páginas adiante repete "membi troante" o que parece que entendia por membi apenas a buzina ameríndia. No Dicionário da língua tupi, designa Gonçalves Dias o membi (sem mais nada), como "buzina, frauta, trombeta". O Clarim (?) dá como sendo entre os índios "Membiapára". (1989, p. 329)

No dossiê de manuscritos do Dicionário musical, dezessete envelopes com notas de trabalho recebem a inscrição "Índios", sempre acrescida de termo que especifica o conteúdo: Instrumento, Religião/Pajé, Dicção, Tribos, Música/Técnica, Danças/Coreografia, Cantos, Festas, Musicalidade. Há referências às Amazonas lendárias, antropofagia, mitos, civilizabilidade do índio, psicologia ameríndia e, no envelope da Musicalidade, notas sobre "canto dos indiozinhos", "meninos cantores", "cantando por cantar", "vaidosos de suas músicas".

No que concerne aos ritmos variados e à musicalidade de Gonçalves Dias, Mário de Andrade sublinha as repetições em "O canto do Piaga":

Eis rebenta a meus pés um fantasma

Um fantasma d'imensa extensão.

e anota, em sua estrofe final: 
Belíssimo. G. Dias o que manejou melhor o ritmo de nove sílabas na língua.

Na "Deprecação", destaca o hemistíquio repetido - "descobre o teu rosto" - e escreve:

Notar a admirável musicalidade dos refrões que perpassam toda a poesia. É delicioso, encantamento sonoro.

Em "Tabira", ainda as repetições interessam, como no verso da nona estrofe, integralmente sublinhado ("Restos são, mas são restos d'um mundo") e o verso final da $15^{\mathrm{a}}$ estrofe, também sublinhado ("O que é gente, o que gente não é").

Em "A mãe-d'água”, Mário sublinha um verso ("Que dentro d'água se vê?") e registra:

Este verso se repete adiante. O conceito musical de repetição de frases é dos mais estilizados por G. Dias e um dos traços mais característicos da poética dele.

A "admirável rítmica" da invocação do Canto II de "Os Timbiras" é louvada, com a ligação dos decassílabos de acentuação heroica e romântica. Mário considera perfeita a pausa natural que, graças à vírgula, desliga a segunda sílaba da palavra "vinda" da partícula que a segue

Tal vinda, a não ser que o audaz Timbira,

[4] "E no entanto o brasileiro de fala mole está se traindo a cada passo no suarabácti” (1959, p. 78). na segunda estrofe do Canto IV. O autor identifica, igualmente, a contagem das sílabas em conformidade com a fala brasileira, como no suarabácti observado também por Manuel Bandeira, em seu estudo sobre Gonçalves Dias ${ }^{4}$. É o caso do verso

Enquanto vivo, insígnias do mando,

na mesma estrofe, no qual Mário observa que o poeta conta o " $g$ " de "insígnia" como sílaba.

Comentários mais alentados permitem entender a avaliação sobre o caráter e a autenticidade do indianismo de Gonçalves Dias. Em "O canto do Piaga", destaca a qualidade dos versos e defende que o indianismo gonçalvino era determinado mais pela inteligência do que pela sensibilidade: 
A piedade de G. Dias pelo índio é uma pura piedade intelectual. O tema indígena foi pra ele mais propriamente um meio de criação artística que um meio de expressão. G. Dias único romântico que foi mais aproximadamente arte-pura. E atinge Camões neste poema.

A nota parece ter implicações profundas, se lembrarmos que boa parte da crítica, antes e mesmo depois de Mário de Andrade, encontrou razões biográficas para a representação de personagens indígenas na poesia de Gonçalves Dias: Silvio Romero e Cassiano Ricardo, por exemplo, explicam o indianismo com base na mestiçagem do poeta, indianismo por eles entendido como expressão íntima da raça.

Cassiano Ricardo reconhece a rejeição do biografismo pela crítica moderna; ressalva, porém, que, no caso de Gonçalves Dias, o nascimento tem "um grave sentido, origem de sua mágoa e do seu indianismo" (1964, p. 143). Ao datar os poemas americanos, teríamos "em carne e osso" o poeta, cuja lírica não passaria de uma recomposição de dados biográficos, e o indianismo, na verdade, uma "forma de ressentimento, mais que de orgulho".

Sílvio Romero encarna mais intensamente a lógica racialista. Para o crítico, o autor de "I-juca-pirama" teria herdado os traços de sua personalidade: dos africanos, a ponta de alegria e o caráter expansivo; dos portugueses, o bom senso, a clareza de ideias, a religiosidade, a energia da vontade, e também as preocupações fantasistas e um certo idealismo; ao passo que dos indígenas teria recebido como legado as melancolias súbitas, a resignação e a passividade ante os acontecimentos. No mesmo sentido, subestimando a influência ameríndia na cultura brasileira, pontua: "um povo que fugiu dificilmente poderia deixar impressos no vulto do que lhe ocupou o lugar os seus toques". Já tendo francamente abandonado a crítica literária, páginas à frente Romero desenvolve seu argumento racista, prevendo que o "tipo branco", após o aproveitamento de outras raças, poderá assumir a preponderância étnica e se exibir "talvez tão depurado e belo" quanto na Europa (1960, p. 161 e seguintes). ${ }^{5}$

Em certa medida, Mário não esteve isento do psico-biografismo, como se percebe no diagnóstico de matriz freudiana dado a Álvares de Azevedo (deixando um tanto de lado as máscaras usadas pelo eu lírico, em favor de uma análise apoiada essencialmente no homem). O manuscrito de "Amor e Medo" demonstra que elementos fisiológicos e raciais não são desconsiderados pelo crítico ${ }^{6}$. O realce à inteligência de Gonçalves Dias, em oposição à sensibilidade, entretanto, rejeita as leituras de viés biográfico-racial então em voga, inclinadas a ver a herança não branca como demérito. Mas não é só isso: as considerações se inserem na dis-
[5] O autor observa o seguinte sobre Sílvio Romero: "A paixão só se manifestou realmente em dois críticos brasileiros. Mas um era uma alma odienta, Sílvio Romero; o outro é uma alma sectária, Tristão de Athayde." (1976, p. 355).

[6] "Estudo fisiológico, hereditariedade racial desnacionalizante, exemplo típico de período de transição na nacionalização racial brasileira, mistura de elementos portugueses e nacionais. Típico ainda pela inteligência, G. D. quer ser brasileiro, ao passo que os outros românticos foram brasileiros inconscientemente." (Manuscrito "Amor e medo", MA-MMA-5-4, IEB/USP) 
cussão mais larga sobre a sinceridade e o artifício, o lirismo espontâneo e o trabalho artístico - essa uma questão-chave na poética mariodeandradiana -, presente, por exemplo, em 1922, na equação de Paul Dermée evocada no "Prefácio interessantíssimo". Em outra nota, à margem do poema "A mangueira", o raciocínio avança:

Realmente só a meio se pode como Alexandre Herculano deplorar não sejam mais numerosas as Poesias Americanas de G. Dias. Só podiam ser mais numerosos os temas geográficos, vegetais do poeta. [...] Com efeito, apesar da vastidão de pensamento de Machado de Assis e da habilidade e riqueza imaginativa de Bilac nada mais se tirou do indianismo, nem mesmo o Evangelho nas Selvas. Só Machado conseguiu ainda uma obra-prima, essa mesma só com uma ligeira base no espiritualismo ameríndio. O Indianismo era necessariamente um tema intelectual, não um moto lírico organizado da sensibilidade que nem a escravidão (vista em redor do poeta), o amor, o lar etc. Daí serem os poetas de inteligência e os artífices grandes como G. D. Machado e Bilac os que se preocuparam com ele.

A insinceridade reconhecida em muitos versos leva Mário a adjetivar o poeta de "romântico à portuguesa", reputando seu romantismo como de escola, "não sincero e franco à brasileira que nem os outros". Na "Canção do exílio", depois de admirar a "musicalidade genial", a marginália ironiza o tratamento da paisagem: "Sabiá cantando na palmeira já muito se falou que só mesmo estudante de Coimbra podia pregar mentirada dessas".

Comparando novamente Gonçalves Dias a Castro Alves, em "O gigante de pedra", as notas de Mário estimam aquele mais "razoável”, pois "não vê unilateralmente uma só desgraça, a do negro, mas mais pensador e sábio, percebe a infelicidade universal".

No desfiar de elogios, o autor de Pauliceia reconhece o "Leito de folhas verdes" como "Sublime. Perfeito. Inigualável". "I-juca-pirama" louvado desde o primeiro tempo modernista, no "Prefácio interessantíssimo" - merece longo comentário:

I-Juca Pirama a grande obra-prima da poesia brasileira em língua portuguesa. Poema a que nada falta, sem falha de concepção, sem falha de realização, unido todo, um marco de literatura universal, a mais perfeita obra literária inspirada pelo exótico existente no mundo. Chateaubriand desaparece. A pureza deste exotismo em comparação com o exotismo romântico dos outros. Não é verdade que os herois de G. Dias estejam vestidos de sentimentos de civilização cristã. São 
selvagens. O jovem tupi morre entre as lagrimas de prazer do pai. G Dias não transporta os seus herois pra dentro de si, transporta-se pra dentro deles, e consegue a inconcebível virtuosidade de realizar os índios num português maravilhoso, perfeito, dando o que melhor tinha de si na musicalidade: no ritmo, na graça levemente arcaizante e amaneirada. É formidável.

A nota descarta, em "I-juca-pirama", a ideia de que a obra indianista de Gonçalves Dias fosse simples medievismo coimbrão. No mesmo poema, o diálogo entre o pai e o filho prisioneiro é qualificado como "grandeza sublime de pobreza".

No Canto II, são assinalados dados etnográficos. O autor sublinha o poder do fumo e marca a lápis: "defumação / catimbó". Grifa o "Impávido Areskí" e anota "Índios, Deus da Guerra". E dá atenção às danças: a dança dos guerreiros, em giro, sublinhada; a dança ritual do piaga, mais à frente; a dança profana:

Com pé alterno a dança vagarosa,

Aos sons do maracá, traçava os passos.

No âmbito do reconhecimento de intertextos, Mário identifica a apropriação de Homero no "descritivo sublime" do poema "Tabira", junto ao verso

Tem um olho d'um tiro frechado!

Da mesma forma, percebe, no arco de Jatir, "o traço homérico, mas sem a riqueza homérica", conforme escreve. Também em "Os Timbiras", valoriza a invocação inicial e fixa como tarefa "compará-la à de Os Lusíadas". Sobre o gênero da obra, uma nota sucinta, ao final:

Os Timbiras, poema lírico...

Para além do diálogo que se deixa ver à margem dos poemas indianistas - travado no despontar da obra madura de Mário de Andrade, no final dos anos 1920 - Telê Ancona Lopez propõe Gonçalves Dias como uma das matrizes de Pauliceia desvairada. A escolha do alaúde no célebre verso de "O trovador" ("Sou um tupi tangendo um alaúde!") estaria ligada a Musset ("Poète, prends ton luth") e ao poema "Canção", no qual o eu lírico distingue os instrumentos conforme o destinatário de seu canto:

[7] "Pode-se ligar a estes versos a abertura da dimensão tupi para o alaúde do trovador de Pauliceia desvairada. [...] O trovador brasileiro, nas pegadas de Gonçalves Dias, devota o alaúde aos 'seus', isto é, a um projeto estético brasileiro e moderno." (LOPEZ, 2002, p. 71). 
[8] A montagem feita por Ângelo Agostini para o periódico Vida Fluminense é reproduzida em Poesia indianista (DIAS, 2002, p. 368).

\author{
Votei assim ao meu Deus \\ A minha harpa religiosa, \\ A ti a lira mimosa, \\ O grave alaúde aos meus!
}

Antecipando o verso modernista, Gonçalves Dias aparece como índio empunhando um alaúde, em fotomontagem de $1882 .{ }^{8}$ Feita a abertura para a dimensão tupi, não será novidade observar que boa parte da obra moderna de Mário se nutriu da cultura indígena, como tema e modo de expressão. Nas anotações líricas de Losango cáqui, São Paulo figura como a taba moderna e crescida:
Mas a taba cresceu...Tigueras agressivas,
Pra trás! Agora o asfalto anda em Tabatinguera
Mal se esgueira um pajé entre locomotivas
$\mathrm{E}$ o forde assusta os manes lentos do Anhanguera.

em Clã do jaboti, entre os foliões do "Carnaval Carioca" há

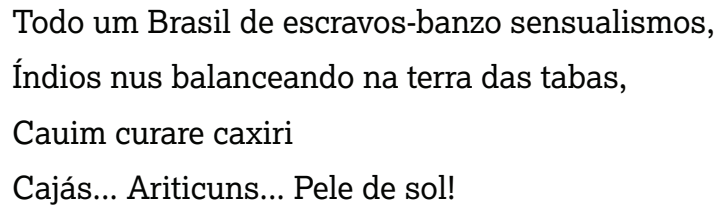

Também no livro de 1927, vale mencionar a "Lenda do céu", apoiada em Capistrano de Abreu, e a "Lenda das mulheres de peito chato", recriada a partir do relato de Koch-Grünberg. O inventário não se esgota e segue com a "Toada do Pai-do-Mato"e o "Rito do irmão pequeno", outros exemplos da matriz ameríndia, difusa, na criação poética de Mário de Andrade. É dos tupis que sai, na confluência com o texto bíblico e a poesia simbolista de Verhaeren, a fórmula

Eu sou aquele que veio do imenso rio

entoada, em 1937, no poema "Brasão"(apropriando-se da fala de Mestre Carlos, do catimbó potiguar) e retomada, em 1942, na concepção melodramática de Café, ópera coral:

EU SOU AQUELE QUE DISSE:

Eu tenho fome! eu tenho muita fome! 
Macunaíma, incorporando a cultura ameríndia no modo de contar e nas narrativas etiológicas recriadas na rapsódia, é outra evidência do interesse que se espraia pela pesquisa etnográfica (as canções acompanhando os Caboclinhos, nas Danças dramáticas; outras anunciando os espíritos do catimbó, em Música de feitiçaria no Brasil; os cantos terenos, relatados por Huaquidí Gathuramo e incluídos em Melodias do boi e outras peças) e se mostra em crônicas e relatos de viagem.

Vistas as linhas de força da marginália indianista e feito o sobrevoo pela poesia de Mário, parece claro que os poemas americanos encontram elos com diversos projetos do autor - as crônicas no Diário Nacional, $A$ gramatiquinha, O banquete, Zoofonia, o Dicionário musical - e se desdobram em variados âmbitos de seus arquivos da criação: o fichário analítico, a correspondência, os dossiês de manuscritos. Pelos traços linguísticos pontuados em Gonçalves Dias (a preposição, o suarabácti, o pleonasmo, os brasileirismos) passa a linha que remete ao estudo e recriação poética da fala brasileira. As vozes animais são úteis ao escritor, assim como ao musicólogo, que se vale das danças e instrumentos para preparar obras voltadas à expressão musical popular. No exame do indianismo romântico, o criador de poéticas reencontra a obsessão pelo tema da sinceridade lírica, e o crítico, em sintonia com a ideia de fecundar a modernidade com traços do pensamento e da expressão selvagem, recusa a hipótese de mera projeção de valores cristãos nos homens ameríndios. ${ }^{9} \mathrm{O}$ entrecruzamento de textos e projetos aponta para muitas faces de Mário de Andrade, polígrafo bricoleur. I
[9] Os dois aspectos aparecem entrelaçados no "Prefácio interessantíssimo": "Não quis também tentar primitivismo vesgo e insincero. Somos na realidade os primitivos duma era nova. Esteticamente: fui buscar entre as hipóteses feitas por psicólogos, naturalistas e críticos sobre os primitivos das eras passadas, expressão mais humana e livre de arte." (ANDRADE, 2013, p. 73).
MARCELO MARANINCHI - Mestrando e bolsista FAPESP/CAPES no Programa de Pós-Graduação Multidisciplinar em Culturas e Identidades Brasileiras do Instituto de Estudos Brasileiros, Universidade de São Paulo - IEB/USP. São Paulo, SP, Brasil. marcelo.maraninchi@usp.br. 


\section{REFERÊNCIAS BIBLIOGRÁFICAS}

ALMEIDA, Aline Novais de. Edição genética d'A gramatiquinha da fala brasileira. Dissertação de Mestrado apresentada ao Programa de PósGraduação em Literatura Brasileira, FFLCH/USP. São Paulo: 2013. Disponível em: <http://www.teses.usp.br/teses/disponiveis/8/8149/tde-24102013102309/>. Acesso em: 2015-05-07.

ANDRADE, Mário de. "Castro Alves". In: Aspectos da literatura brasileira. São Paulo: Livraria Martins, 1974.

-. O banquete. São Paulo: Duas Cidades, 1977.

-. Dicionário musical brasileiro. Edição preparada por Oneyda Alvarenga e Flávia Toni. Belo Horizonte: Itatiaia, Brasília: Ministério da Cultura, São Paulo: IEB-USP/ Edusp, 1989.

-. Entrevistas e depoimentos. Edição organizada por Telê Ancona Lopez. São Paulo: T. A. Queiroz, 1983,

-. Poesias completas. Edição de texto apurado, anotada e acrescida de documentos por Tatiana Longo Figueiredo e Telê Ancona Lopez. Rio de Janeiro: Nova Fronteira, 2013

-. Táxi e Crônicas no Diário Nacional. São Paulo: Duas Cidades, Secretaria da Cultura, Ciência e Tecnologia, 1976.

BANDEIRA, Manuel. "A poética de Gonçalves Dias”. In: DIAS, Gonçalves. Poesia completa e prosa escolhida. Rio de Janeiro: Editora José Aguilar, 1959.

DIAS, Gonçalves. "Epistolário Acadêmico - Uma carta de Gonçalves Dias”. In: Revista da Academia Brasileira de Letras. Vol. 38, ano 23, no 121, Rio de Janeiro: Est. Gr. Canton\&Reile, 1932.

-. Poesia indianista. Introdução, organização e fixação de texto de Márcia Lígia Guidin. São Paulo: Martins Fontes, 2002

LOPEZ, Telê Porto Ancona. "A biblioteca de Mário de Andrade: seara e celeiro da criação". In: ZULAR, Roberto, org. Criação em processo: Ensaios de crítica genética. São Paulo: FAPESP/ Iluminuras/ CAPES, 2002, 
MORAES, Marcos Antonio (org. introd. e notas). Correspondência Mário de Andrade \& Manuel Bandeira. 2ª ed. São Paulo, Edusp/IEB, 2001, pp. 210 e 490.

RICARDO, Cassiano. O indianismo de Gonçalves Dias. São Paulo: Conselho Estadual de Cultura, 1964.

ROMERO, Sílvio. Historia da litteratura brasileira. Rio de Janeiro: José Olympio, 1960.

SCHWARZ, Roberto. "Nacional por subtração”. In: Que horas são? São Paulo: Companhia das Letras, 2006. 